\title{
FORMULATION AND APPLICATION OF NANOSILVER-INFUSED CREAM IN PREVENTION AND TREATMENT OF MASTITIS IN DAIRY COWS
}

\author{
Nguyen Hoai Chau ${ }^{1}$, Dao Trong Hien ${ }^{1}$, Nguyen Thi Thuy ${ }^{1}$, Doan Quang Ha ${ }^{1}$, \\ Dang Thi Duong ${ }^{2}$, Tran Thi Loan ${ }^{2}$, Phung Thi Dieu Linh', \\ Tang Xuan Luu', Ngo Dinh Tan', Tran Van Tua ${ }^{1, *}$ \\ ${ }^{1}$ Institute of Environmental Technology, VAST, Vietnam \\ ${ }^{2} \mathrm{Ba}$ Vi Cattle and Forage Research Centrer, National Institute of Animal Science, Vietnam
}

Received 26 March 2019, accepted 18 May 2019

\begin{abstract}
Research on formulation of nanosilver-infused cream was carried out at the Institute of Environmental Technology and the effects of this cream in prevention and treatment of mastitis in dairy cows were assessed at Bavi Cattle and Forage Research Center. Cream with 0.4\% carbomer was infused with silver nanoparticles for high uniformity and long-term stability. At concentrations of 50-250 ppm, nanosilver-infused cream proved to be effective against mastitis pathogens such as Escherichia coli, Staphylococcus aureus, Pseudomonas aeruginosa. Nanosilver cream at concentrations of $150 \mathrm{ppm}$ had the best effect on clinical and subclinical mastitis prevention in dairy cows. Combining nanosilver cream with ceftiofer antibiotic achieved excellent treatment rate, up to $93.33 \%$. For prevention of dairy mastitis, silver cream can be used at a concentration of $150 \mathrm{ppm} 15$ days before calving and for the whole milking period. Using nanosilver cream in combination with antibiotics led to highly effective mastitis treatment.
\end{abstract}

Keywords: Dairy cows, mastitis, prevention, nanosilver cream, treatment.

Citation: Nguyen Hoai Chau, Dao Trong Hien, Nguyen Thi Thuy, Doan Quang Ha, Dang Thi Duong, Tran Thi Loan, Phung Thi Dieu Linh, Tang Xuan Luu, Ngo Dinh Tan, Tran Van Tua, 2019. Formulation and application of Nanosilver-infused cream in prevention and treatment of mastitis in dairy cows. Tap chi Sinh hoc, 41(2): 89-100. https://doi.org/10.15625/0866-7160/v41n2.13707.

*Corresponding author email: tranvantua@gmail.com

(O2019 Vietnam Academy of Science and Technology (VAST) 


\title{
NGHIÊN CÚU CHẾ TẠO VÀ SỬ DỤNG KEM NANO BẠC TRONG PHÒNG VÀ TRI BÊNH VIÊM VÚ BÒ SỬA
}

\author{
Nguyễn Hoài Châu ${ }^{1}$, Đào Trọng Hiền ${ }^{1}$, Nguyễn Thị Thúy ${ }^{1}$, Đoàn Quang Hà ${ }^{1}$, \\ Đặng Thị Dương ${ }^{2}$, Trân Thị Loan², Phùng Thị Diệu Linh', \\ Tăng Xuân Lưư ${ }^{2}$ Ngô Đình Tân², Trần Vắn Tựa ${ }^{1, *}$
}

${ }^{1}$ Viện Công nghệ môi trường, Viện Hàn lâm Khoa học và Công nghệ Việt Nam, Việt Nam

${ }^{2}$ Trung tâm Nghiên cứu Bò và đồng cỏ Ba Vì, Viện Chăn nuôi Quốc gia, Việt Nam

Ngày nhận bài 26-3-2019, ngày chấp nhận 18-5-2019

\section{TÓM TÁT}

Nghiên cứu chế tạo kem chứa nano bạc được thực hiện tại Viện Công nghệ môi trường và nghiên cứu sử dụng kem trong chăn nuôi bò sữa do Trung tâm nghiên cứu bò và đồng cỏ $\mathrm{Ba}$ Vì thực hiện.

Kết quả nghiên cứu đã lựa chọn carbomer $4 \%$ làm chất tạo kem kết hợp với nano bạc tạo thành chế phẩm kem nano bạc có độ đồng nhất cao và ổn định lâu dài về màu săc, độ đồng nhất, kích thước và hàm lượng nano bạc.

Kem nano bạc hàm lượng 50-250 ppm có khả năng kháng rất mạnh các loài vi khuẩn như Escherichia coli, Staphylococcus aureus, Pseudomonas aeruginosa gây bệnh viêm vú. Kem nano bạc 150 ppm có tác dụng tối đa trong phòng bệnh viêm vú lâm sàng và cận lâm sàng của bò trước khi đẻ. Sử dụng kem nano bạc 150 ppm kết hợp với kháng sinh ceftiofer cho hiệu quả điều trị cao đạt đến 93,33\%.

Kết quả nghiên cứu còn cho thấy có thể sử dụng kem nano bạc 150 ppm trong phòng bệnh viêm vú bò sữa trước khi đẻ 15 ngày và toàn bộ thời gian trong giai đoạn vắt sữa. Sử dụng kết hợp kem nano bạc trong điều trị bệnh viêm vú với kháng sinh đưa lại hiệu quả cao.

Từ khóa: Bệnh viêm vú, bò sữa, điều trị, kem nano bạc, phòng bệnh.

*Địa chỉ liên hệ email: tranvantua@gmail.com

\section{MỞ ĐẦU}

Viêm vú ở bò sữa là bệnh gây thiệt hại lớn về kinh tế bao gồm giảm khả năng sản xuất sữa, chi phí điều trị, chi phí nhân công và có thể loại thải nếu bệnh kéo dài. Nguyên nhân chính gây bệnh viêm vú bò sữa là các loài vi khuẩn Streptococcus uberis, Escherichia coli, Staphylococcus aureus và Pseudomonas aeruginosa (Bradley et al., 2007; Idriss et al., 2014).

Các phương pháp thông thường ngăn ngừa bệnh viêm vú đã được sử dụng như thuốc nhúng đầu vú trước và sau khi vắt sữa cũng như phun tẩy trùng dụng cụ, phương tiện khai thác sữa như Haniodin, Lugol, nước gia ven, cloramin... Các chất này tuy có hiệu quả nhất định nhưng cũng gây hiệu ứng bất lợi cho gia súc như làm tổn thương lớp da non, làm khô da.

Để khắc phục bệnh viêm vú bò sữa, một số loại kem dạng mỡ có chất khử trùng và một số thành phần có nguồn gốc thực vật và các chất hữu cơ phụ trợ khác thường được dùng để bôi lên da vú bò. Các loại kem này có tác dụng chung là khắc phục tình trạng da vú bò 
bị khô, duy trì tính đàn hồi và mềm; làm vết thương ở đó không bị nhiễm trùng và chóng liền da; tránh bị các loại ve, ruồi châm đốt; giảm tác động của môi trường như ánh nắng và gió bụi lên vú bò.

Điều trị cho bò bị viêm vú bằng kháng sinh tiêm bắp hoặc tiêm trực tiếp vào bầu vú. Các kháng sinh sử dụng là Kanamicin, Gentamycin, Bio-Amox, Bio-Genta, Hamogen. Phương pháp chữa bệnh này có hiệu quả cao nhưng sau khi tiêm thuốc kháng sinh, trong thời gian đầu, sữa bò bắt buộc phải bỏ, do trong sữa có hàm lượng chất kháng sinh, không đáp ứng với những chỉ tiêu qui định về sữa bò. Mặt khác, hiện tượng kháng kháng sinh xảy ra ngày càng nhanh và mạnh đòi hỏi các thuốc kháng khuẩn diệt khuẩn mới và phương pháp điệu trị hiệu quả hơn (Berni et al., 2012).

Ngày nay, công nghệ nano phát triển nhanh và được ứng dụng rộng rãi trong nhiều lĩnh vực khác nhau. Nano bạc có khả năng diệt nấm và vi khuẩn rất mạnh với nồng độ thấp và hiệu quả diệt khuẩn cao của nano bạc là một trong những lựa chọn mới cho việc làm giảm sự phát triển của vi khuẩn (Wilson, 2012). Nano bạc đã được chứng minh là có tiềm năng chống lại vi khuẩn ở phổ rộng (Humberto et al., 2011). Việc giải phóng ion bạc và việc phối hợp giữa kháng sinh và nano bạc đã được chứng minh hiệu quả trong việc diệt khuẩn, chống lại sự kháng kháng sinh của chúng (Birla et al., 2009). Nhiều nghiên cứu về tác dụng diệt khuẩn của nano bạc được thực hiện và chứng minh ở qui mô trang trại (Perugini et al., 2015). Cùng với khả năng diệt khuẩn và nấm cao vì chỉ với nồng độ rất thấp, nano bạc không gây hại cho con người, động vật. Đồng thời, bạc khồng tích tụ trong cơ thể mà có thể thải ra ngoài qua các con đường khác nhau.

Kem bôi da là dạng thuốc bán rắn, có chứa một hoặc nhiều dược chất dược hoà tan hay phân tán vào tá dược thích hợp. Tá dược là môi trường phân tán, có tác dụng tiếp nhận, bảo quản, giải phóng dược chất và dẫn thuốc qua. Nó phải có khả năng tạo thành một chất dồng đều, trong đó dược chất dễ đạt độ phân tán cao. Có $\mathrm{pH}$ trung tính hoặc acid nhẹ, gần giống với $\mathrm{pH}$ của da. Không cản trở hoạt động sinh lý bình thường của da, không làm khô và gây kích ứng da. Phải bền vững về mặt lý-hoá, không dễ bị hỏng bởi nấm mốc và vi khuẩn. Để chế tạo kem bôi da, ngoài hoạt chất cần sử dụng tá dược thích hợp.

Ở Việt Nam, nghiên cứu sử dụng nano bạc trong chẳn nuôi bò sữa nói chung và phòng trị bệnh viêm vú nói riêng còn chưa được quan tâm. Bài báo này trình bày về kết quả nghiên cứu chế tạo kem chứa nano bạc và đánh giá tác dụng của kem nano bạc đến hiệu quả phòng trị bệnh viêm vú ở bò sữa.

\section{VÂT LIỆU VÀ PHƯƠNG PHÁP NGHIÊN CưU}

Ba chủng vi sinh vật: $E$. coli (ATCC 14169), Staphylococcus aureus, và Pseudomonas aeruginosa (ATCC 27853) dùng trong nghiên cứu khả năng kháng khuẩn do Viện Vi sinh vật và Công nghệ sinh học (USA) cung cấp. Thực nghiệm tiến hành tại Viện Công nghệ mồi trường, Viện Hàn lâm Khoa học và Công nghệ Việt Nam.

Bò dùng đánh giá khả năng phòng trị bệnh viêm vú của kem nano bạc là đàn bò sữa đang ở độ tuổi sinh sản cạn sữa và giai đoạn khai thác sữa của Trung tâm nghiên cứu Bò và Đồng cỏ Ba Vì, Viện Chăn nuôi Quốc gia.

\section{Phương pháp nghiên cứu}

Quy trình chế tạo $1 \mathrm{~kg}$ kem nano bạc (nồng độ nano bạc 150 ppm theo các bước sau: $300 \mathrm{ml}$ dung dịch nano bạc được cho vào bể phản ứng, thêm nước cất và khuấy 1.000 vòng/phút trong 3-5 phút; dùng một lượng polyme khảo sát (carboxymethiylcellulose (CMC), alginat hoặc carbomer) được thêm vào hỗn hợp ở bước (1), khuấy 1.000 vòng/phút trong 60-90 phút; thêm tá dược vừa đủ; khuấy 1.000 vòng/phút trong $15-30$ phút thu được sản phẩm cuối cùng là kem nano bạc màu vàng nâu.

\section{Đánh giá khả năng phòng bệnh viêm vú:}

Đối với bò vắt sữa: 100 bò đang khai thác sữa chia ngẫu nhiên, 50 bò thí nghiệm (TN), 50 bò đối chứng (ĐC). Dùng kem nano bạc bôi đều lên 4 núm vú, với vú bị viêm bối 
lên cả thùy vú, bôi ngày 2 lần. Lô ĐC nhúng vú bằng dung dịch iodine $1 \%$ ngày 2 lần sau vắt sữa;

Đối với bò can sữa: 50 bò can sữa chia ngẫu nhiên thành 2 lô đều nhau. Lô TN bôi đều lên 4 núm vú ngày 2 lần trước khi để 10
15 ngày. Lô $\mathrm{C}$ nhúng vú bằng bằng dung dịch iodine $1 \%$ ngày 2 lần;

Đánh giá khả năng điều trị bệnh viêm vú bằng cách chọn ra 45 bò bị viêm vú dạng lâm sàng và đưa vào thí nghiệm điều trị với bố trí như ở bảng 1 .

Bảng 1 . Phác đồ điều trị bò sữa viêm vú lâm sàng

\begin{tabular}{|l|c|c|c|}
\hline Tiêu chí & Phác đồ 1 & Phác đồ 2 & Phác đồ 3 \\
\hline Số bò TN (con) & 15 & 15 & 15 \\
\hline Thuốc & Nano bạc & $\begin{array}{c}\text { Ceftionel-50, } \\
\text { Novacin }\end{array}$ & $\begin{array}{c}\text { Ceftionel-50, Novacin, } \\
\text { Nano bạc }\end{array}$ \\
\hline Phương pháp & $\begin{array}{c}\text { Bôi đều lên bầu } \\
\text { vú và núm vú }\end{array}$ & Tiêm bắp & $\begin{array}{c}\text { Kết hợp cả hai phương pháp } \\
\text { như phác đồ } 1 \text { và } 2\end{array}$ \\
\hline Thời gian điều trị & 5 ngày & 5 ngày & 5 ngày \\
\hline
\end{tabular}

Bôi kem nano bạc: Sau khi vắt sữa xong, lấy kem nano bạc bôi và xoa đều lên bầu vú và núm vú dày $1 \mathrm{~mm}$, ngày 2 lần; Ceftionel50 , thành phần Ceftiofur $5 \%$ do Hà Lan sản xuất được tiêm bắp với liều lượng $1 \mathrm{ml} / 50 \mathrm{~kg}$ $\mathrm{P}$, ngày 1 lần sau khi vắt sữa; Novacin: Thuốc tiêu viêm, giảm đau không steroid, tiêm bắp với liều lượng $1 \mathrm{ml} / 25 \mathrm{~kg} \mathrm{P}$, ngày 1 lần sau khi vắt sữa.

Đánh giá độ đồng nhất của kem nano bạc theo mô tả của Trần Tích (2007); đánh giá các chỉ sức khỏe núm vú: Sử dụng phương pháp của Mein et al. (2001); đánh giá viêm vú cận lâm sàng: Bệnh viêm vú cận lâm sàng được chẩn đoán bằng phương pháp $\mathrm{CMT}$ (California Mastitis test) (Anri et al., 2002).

Phương pháp xác định bò mắc bệnh viêm vú lâm sàng: Thông qua biểu hiện toàn thân như sốt, bỏ ăn, và các đặc điểm sưng nóng, đỏ đau của bầu vú , mầu sắc của sữa tại thời điểm thí nghiệm; phân lập vi khuẩn có trong sữa: Theo phương pháp của Nguyễn Như Thanh và nnk. (1997); phân biệt và nhận biết các vi khuẩn gây bệnh viêm vú theo Anri et al. (2005); đếm tế bào somatic (SCC): Bằng máy đếm SCC chuyên dụng.

Phương pháp đánh giá khả năng diệt khuẩn của kem nano bạc: Sử dụng phương pháp khuếch tán qua giếng thạch (agar well diffusion method). Quy trình gồm các bước sau:
Chuẩn bị dịch vi khuẩn: cấy vi khuẩn trên môi trường thạch $\mathrm{PCA}$ và nuôi ủ ở nhiệt độ $37^{\circ} \mathrm{C}$. Sau 24 giờ, vi khuẩn được thu trong ông nghiệm nước $\mathrm{RO}$ và bảo quản trong điều kiện nhiệt độ thấp $3-4^{\circ} \mathrm{C}$. Dịch vi khuẩn được định lượng dựa vào nguyên tắc pha loãng theo dãy thập phân và phương pháp đổ hộp;

Tạo vòng kháng: Môi trường thạch PCA được đổ vào đĩa petri đã khử trùng và được để qua đêm. Dùng pipet hút $100 \mu 1$ dịch vi khuẩn vào đĩa thạch $\mathrm{PCA}$. Sử dụng que trải để trải đều vi khuẩn trên bề mặt môi trường thạch đến khi bề mặt môi trường khô ráo. Đục các giếng có đường kính $5 \mathrm{~mm}$ và hút gel nano bạc ở các nồng độ $0-250$ ppm vào từng giếng. Nuôi ủ ở nhiệt độ $37^{\circ} \mathrm{C}$ và đo đường kính vòng kháng khuẩn sau 24-36 giờ nuồi cấy. Phương pháp lấy mẫu sữa theo Anri \& Kanameda (2002).

Số liệu thu thập được sẽ được xử lý thống kê bằng phép phân tích phương sai ANOVA trên phần mêm Minitab phiên bản 16.0 dạng thiết kế thí nghiệm 1 nhân tố. Sử dụng phương pháp Chi-Square để so sánh.

\section{KẾT QUẢ VÀ THẢO LUẬN}

Ảnh hưởng của chất tạo kem - polymer đến màu sắc và độ đồng nhất của kem nano bạc

Để chế tạo kem bôi da, ngoài hoạt chất cần sử dụng tá dược thích hợp trong đó có chất tạo gel. Trong nghiên cứu này, $\mathrm{CMC}$ 
được sử dụng nồng độ từ 0,5 đến $2,0 \%$; nồng độ alginat được khảo sát từ 0,5 đến $2,0 \%$ và nồng độ carbomer từ 0,1 đến $0,4 \%$.
Kết quả kiểm tra độ đồng nhất của các mẫu kem nano bạc ngay sau chế tạo được chỉ ra ở bảng 2.

Bảng 2. Độ đồng nhất của kem nano bạc sử dụng tá dược khác nhau

\begin{tabular}{|c|c|c|c|c|c|c|}
\hline \multirow{2}{*}{ TT } & \multicolumn{2}{|c|}{ CMC } & \multicolumn{2}{c|}{ Alginat } & \multicolumn{2}{c|}{ Carbomer } \\
\cline { 2 - 7 } & Nồng độ $(\%)$ & $\begin{array}{c}\text { Độ đồng } \\
\text { nhất }\end{array}$ & $\begin{array}{c}\text { Nồng độ } \\
(\%)\end{array}$ & $\begin{array}{c}\text { Độ đồng } \\
\text { nhất }\end{array}$ & $\begin{array}{c}\text { Nồng độ } \\
(\%)\end{array}$ & $\begin{array}{c}\text { Độ đồng } \\
\text { nhất }\end{array}$ \\
\hline 1 & 0,5 & Đồng nhất & 0,5 & Đồng nhất & 0,1 & Đồng nhất \\
\hline 2 & 1,0 & Đồng nhất & 1,0 & Đồng nhất & 0,2 & Đồng nhất \\
\hline 3 & 2,0 & Đồng nhất & 2,0 & Đồng nhất & 0,3 & Đồng nhất \\
\hline 4 & - & - & - & - & 0,4 & Đồng nhất \\
\hline
\end{tabular}

Số liệu bảng 2 cho thấy, sau khi chế tạo, cả 3 loại polymer với các nồng độ khác nhau thử nghiệm đều cho độ đồng nhất. Tuy nhiên, sau 3 tháng bảo quản, kem sử dụng $\mathrm{CMC}$ và alginat có sự thay đổi, màu của kem đậm hơn có thể do các hạt nano bạc đã bị oxy hóa làm thay đổi màu sắc của kem. Riêng kem sử dụng carbomer không có sự thay đổi. Kuma \& Parida (2015) đã sử dụng carbomer làm chất tạo gel nano bạc như sau: carbomer $(2 \%)$, glycerol (2\%), nano bạc (200ppm), nước cât vừa đủ $100 \mathrm{~g}$. Các kết quả đánh giá đặc trưng của sản phẩm và hoạt tính kháng khuẩn của gel nano bạc chế tạo được cũng tương đương với nghiên cứu này. Vî vậy, carbomer được sử dụng cho các nghiên cứu tiếp theo.

\section{Ảnh hưởng của hàm lượng nano bạc trong kem đến màu sắc và độ đồng nhất của kem nano bạc}

Hàm lượng nano bạc thấp làm giảm tác dụng diệt khuẩn của kem nano bạc. Ngược lại, hàm lượng nano bạc cao có thể dẫn đển sự tập hợp của các hạt nano thành các hạt lớn hơn, giảm hiệu quả diệt khuẩn và rút ngắn thời hạn sử dụng. Kết quả nghiên cứu ảnh hưởng của hàm lượng nano bạc trong kem đến màu sắc và độ đồng nhất của kem nano bạc, các mẫu kem nano bạc chế tạo được đều có màu vàng nâu và đậm dần theo hàm lượng bạc (hình 1 , bảng 3).
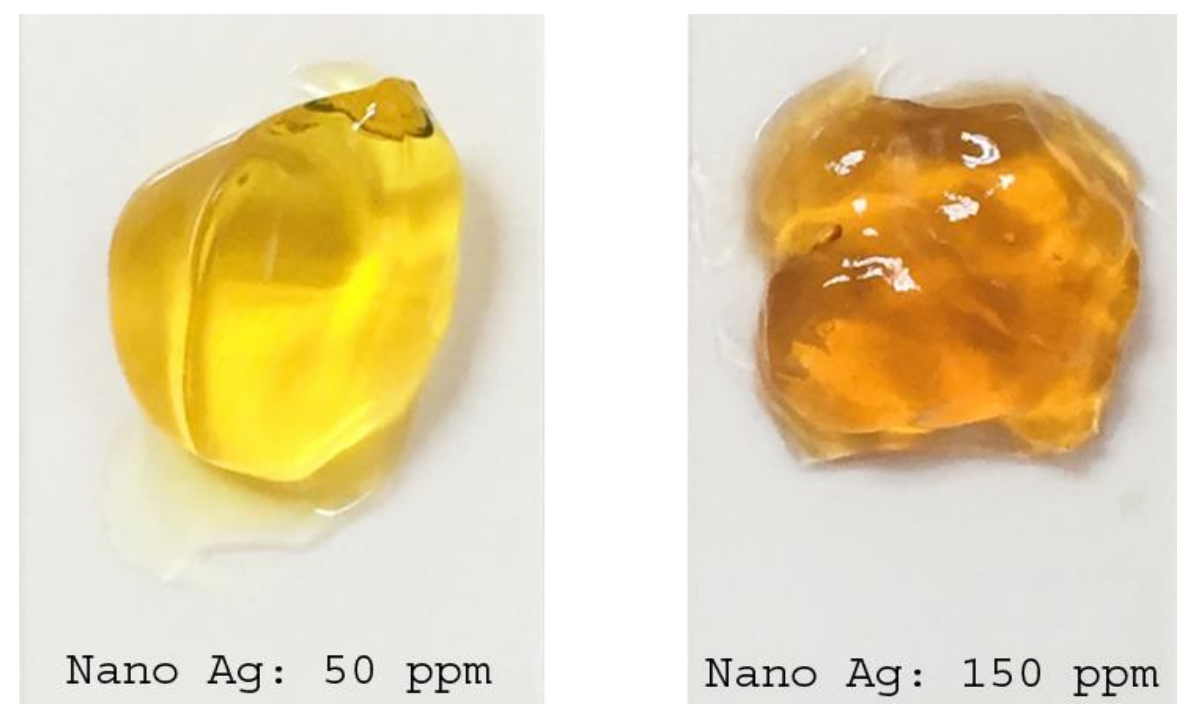

Hình 1. Mẫu kem nano bạc chế tạo với hàm lượng khác nhau 
Bảng 3. Ảnh hưởng của hàm lượng nano bạc đến màu sắc và độ đồng nhất của kem bôi

\begin{tabular}{|c|c|c|c|c|}
\hline TT & Nano bạc $(\mathrm{ppm})$ & $\mathrm{pH}$ & Màu sắc* & Độ đồng nhất \\
\hline 1 & 50 & 5,57 & Màu vàng nhạt & Đồng nhất \\
\hline 2 & 100 & 5,05 & Màu vàng nhạt & Đồng nhất \\
\hline 3 & 150 & 4,93 & Màu vàng nâu & Đồng nhất \\
\hline 4 & 200 & 4,76 & Màu nâu nhạt & Đồng nhất \\
\hline 5 & 250 & 4,52 & Màu nâu đen & Đồng nhất \\
\hline
\end{tabular}

Ghi chú: *: màu sắc của kem sau 3 tháng bảo quản.

Số liệu ở bảng 3 cho thấy, $\mathrm{pH}$ của kem nano bạc giảm dần khi tăng hàm lượng bạc, điều này có thể giải thích khi hàm lượng của nano bạc trong kem tăng, tương ứng hàm lượng chitosan cũng cao hơn vì chitosan được sử dụng làm chất phân tán khi chế tạo dung dịch nano bạc.

Kết quả kiểm tra độ đồng nhất của các mẫu kem nano bạc ngay sau chế tạo cho thấy, tất cả các mẫu kem khi thay đổi về nồng độ nano bạc không quan sát thấy các vết của tiểu phân nano bạc, điều này cho thấy các mẫu kem nano bạc đều ổn định và đồng nhất.

Đánh giá sự ổn định của kem nano bạc theo thời gian bảo quản
Các mẫu kem nano bạc sau khi chế tạo được bảo quản trong lọ nhựa kín, tối màu. Sau các thời gian bảo quản $3,6,12,18$ và 24 tháng, mẫu được đem đánh giá đặc trưng về độ đồng nhất, hàm lượng bạc và kích thước hạt nano bạc trong kem. Kết quả thu được cho thấy, tất cả các mẫu kem nano bạc theo thời gian bảo quản đều ổn định và đồng nhất (bảng 4). Sau 24 tháng bảo quản, không quan sát thây các vết của tiểu phân nano bạc ở tất cả các mẫu. Như vậy, kem nano bạc có độ đồng nhất khá tốt. Với hàm lượng bạc ban đầu là $150 \mathrm{ppm}$, kết quả phân tích hàm lượng bạc trong mẫu kem cho thấy, hàm lượng bạc nano trong kem tương đối ổn định theo thời gian bảo quản với sai khác không đáng kể (hình 2).

Bảng 4. Kết quả phân tích hàm lượng bạc và độ đồng nhất của kem bảo quản

\begin{tabular}{|c|c|c|c|}
\hline STT & Thời gian bảo quản (tháng) & Độ đồng nhất & Hàm lượng phân tích $(\mathrm{ppm})$ \\
\hline 1 & 3 & dồng nhất & $153,6 \pm 4,12$ \\
\hline 2 & 6 & đồng nhất & $157,3 \pm 7,84$ \\
\hline 3 & 12 & dồng nhất & $149,4 \pm 1,28$ \\
\hline 4 & 18 & dồng nhất & $150,2 \pm 2,16$ \\
\hline 5 & 24 & dồng nhất & $148,7 \pm 2,92$ \\
\hline
\end{tabular}

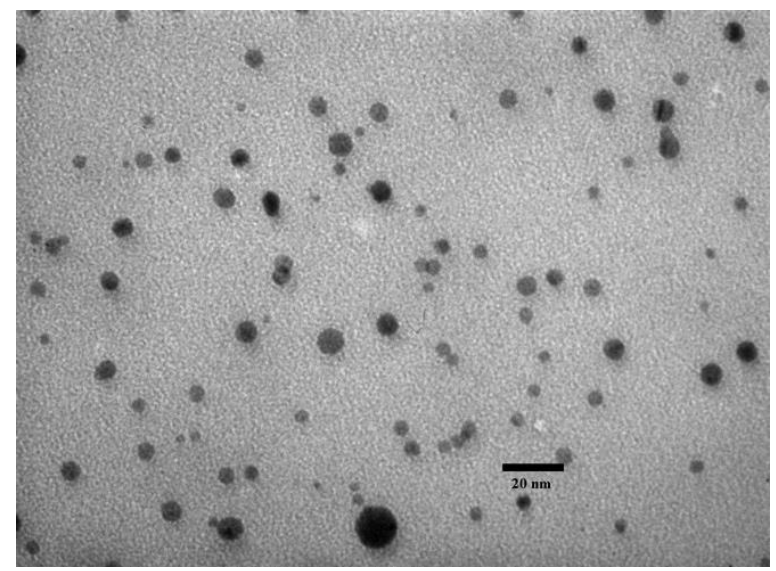

Hình 2. Ảnh TEM mẫu kem nano bạc sau 24 tháng bảo quản 
Kết quả chụp ảnh TEM cho thấy các hạt nano bạc trong kem bảo quản sau 3, 6, 12, 18 và 24 tháng đều có dạng hình cầu với kích thước nhỏ trung bình từ $8-15 \mathrm{~nm}$ và phân bố đồng đều. Điều này chứng tỏ, theo thời gian bảo quản, kích thước các hạt nano bạc trong kem không bị thay đổi.

Đánh giá hoạt tính diệt khuẩn của kem nano bạc sử dụng carbomer

Kết quả đánh giá hoạt tính diệt khuẩn $E$. coli của kem nano bạc sử dụng carbomer sau khi chế tạo được trình bày ở bảng 5 .
Kết quả cho thấy, với nồng độ nano bạc 150 ppm trong kem, khi sử dụng Carbomer ở các nồng độ $0,1-0,4 \%$ đều thể hiện hoạt tính diệt khuẩn tốt, với $E$. coli nồng độ $1,2 \times 10^{3}$ đã bị diệt hoàn toàn, hiệu lực diệt khuẩn đạt $100 \%$. Tuy nhiên, đối với mẫu kem nano bạc có hàm lượng carbomer thấp $(0,1 \%)$ khi tiếp xúc với môi trường nuôi cấy vi sinh thì khả năng phân tán không tốt, mẫu kem có hiện tượng kết tụ lại. Để thực hiện cho các nghiên cứu tiếp theo, nhóm nghiên cứu đã lựa chọn hàm lượng carbomer $0,4 \%$.

Bảng 5. Hiệu quả diệt khuẩn của kem nano bạc sử dụng Carbomer

\begin{tabular}{|c|c|c|c|}
\hline Mẫu & Nồng độ Carbomer $(\%)$ & Nồng độ E.coli $(\mathrm{CFU} / \mathrm{mL})$ & Hoạt lực diệt khuẩn $(\%)$ \\
\hline ĐC & 0 & $1,2 \times 10^{3}$ & - \\
\hline Car-0,1 & 0,1 & 0 & 100 \\
\hline Car-0,2 & 0,2 & 0 & 100 \\
\hline Car-0,3 & 0,3 & 0 & 100 \\
\hline Car-0,4 & 0,4 & 0 & 100 \\
\hline
\end{tabular}

Nghiên cứu ảnh hưởng của kem nano bạc đến khả năng diệt vi khuẩn gây viêm vú bò sữa $E$. coli, $P$. aeruginosa và $S$. aureus

Khả năng kem nano bạc diệt vi khuẩn gây viêm vú như $E$. coli, $P$. aeruginosa và $S$. aureus được đánh giá bằng phương pháp khuếch tán qua giếng thạch dựa trên đường kính vòng kháng khuẩn của kem nano bạc trên đĩa thạch đã trải 3 loại vi khuẩn này và được nuôi trong điều kiện $37^{\circ} \mathrm{C}$. Sau 24 giờ, kết quả đạt được trình bày ở bảng 6 .

Có thể thấy kem không chứa nano bạc không có khả năng diệt khuẩn. Khả năng diệt khuẩn của kem tỉ lệ thuận với hàm lượng nano bạc trong kem, hàm lượng nano bạc càng cao, biểu hiện diệt khuẩn của kem càng cao, đường kính vòng kháng càng lớn.

Bảng 6. Vòng kháng khuẩn của kem nano bạc đối với một số loài vi khuẩn gây viêm vú trên bò sữa

\begin{tabular}{|l|c|c|c|c|c|c|c|}
\hline $\begin{array}{l}\text { Hàm lượng nano bạc } \\
\text { trong kem }\end{array}$ & $\begin{array}{c}\text { Iodine } \\
1 \%\end{array}$ & $\begin{array}{c}0 \\
\mathrm{ppm}\end{array}$ & $\begin{array}{c}50 \\
\mathrm{ppm}\end{array}$ & $\begin{array}{c}100 \\
\mathrm{ppm}\end{array}$ & $\begin{array}{c}150 \\
\mathrm{ppm}\end{array}$ & $\begin{array}{c}200 \\
\mathrm{ppm}\end{array}$ & $\begin{array}{c}250 \\
\mathrm{ppm}\end{array}$ \\
\hline $\begin{array}{l}\text { Đường kính vòng kháng } \\
\text { E. coli }\end{array}$ & & 0 & 11 & 11,5 & 12 & 12,5 & 13 \\
\hline $\begin{array}{l}\text { Đường kính vòng kháng } \\
\text { P. aeruginosa }\end{array}$ & & 0 & 11 & 11,5 & 12 & 12,5 & 13 \\
\hline $\begin{array}{l}\text { Đường kính vòng kháng } \\
\text { S. aureus }\end{array}$ & 11 & - & 11 & 11,5 & 12 & 12,5 & 13 \\
\hline
\end{tabular}

Kết quả nghiên cứu này tương tự với kết luận của Akmaz et al. (2013) khi sử dụng hàm lượng nano bạc ở mức 100 đến 200 ppm có tác dụng diệt $E$. coli. Nghiên cứu của Marslin et al. (2015) cũng chỉ ra kem chứa nano bạc ức chế mạnh lên sinh trưởng của các vi khuẩn 
Staphylococcus aureus, Pseudomonas aeruginosa, E. coli. So với kem chứa muối bạc, hoạt tinh ức chế của kem nano bạc lên các vi khuân này cao hơn lần lượt là 200,31 và 28 lần tương ứng.

Số liệu ở bảng 6 cũng chỉ ra kem nano bạc $50 \mathrm{ppm}$ có đường kính vòng kháng bằng vòng kháng của iodine $1 \%$. Như vậy, kem nano bạc 50 ppm có khả năng diệt khuẩn tương đương với iodine $1 \%$, loại dung dịch được các trang trại, nông dân thường sử dụng trong khử trùng vú bò.

So sánh đường kính vòng kháng khuẩn cho thấy khi tăng hàm lượng bạc, đường kính vòng kháng khuẩn tăng lên không nhiểu. Để vừa hiệu quả vừa kinh tế trong sử dụng nano bạc, chúng tôi chọn kem chứa 150 ppm nano bạc cho nghiên cứu trong phòng và trị bệnh viêm vú bò sữa.

\section{Khả năng phòng bệnh viêm vú của kem nano bạc ở giai đoạn tiết sữa}

Kết quả bảng 7 cho thấy, màu sắc núm vú, độ khô của da và sự sừng hóa xung quanh lỗ núm vú của nhóm bò được sử dụng kem nano bạc đều tốt hơn so với nhóm không dùng. Đặc biệt là độ khô của da và sự sừng hóa xung quanh lỗ núm vú cho thấy nhóm bò được sử dụng kem nano bạc có tỷ lệ da bình thường (không thô và khô) cao hơn hẳn so với nhóm bò đối chứng $(\mathrm{P}<0,05)$. Kết quả này cho thấy, đối với bò bị viêm vú khi sử dụng kem nano bạc đã đảm bảo được sức khỏe núm vú tốt hơn so với các biện pháp điều trị thông thường hiện nay.

Bảng 7. Kết quả đánh giá tình trạng sức khỏe bầu vú bò đang vắt sữa

\begin{tabular}{|l|l|c|c|c|}
\hline \multicolumn{2}{|l|}{ Chỉ tiêu } & Lô TN & Lô ĐC & \multirow{2}{*}{$\mathrm{P}$} \\
\hline \multicolumn{2}{|l|}{ Số bò thí nghiệm n (con) } & 50 & 50 & \\
\hline \multirow{2}{*}{ Màu sắc } & Bình thường (con) & $40 / 50(80 \%)$ & $37 / 50(74 \%)$ & \multirow{3}{*}{0,05} \\
\cline { 2 - 4 } & Sưng, đỏ & $10 / 50(20 \%)$ & $13 / 50(26 \%)$ & \\
\hline \multirow{2}{*}{ Độ khô của da } & Bình thường (con) & $50 / 50(100 \%)$ & $31 / 50(19 \%)$ & \multirow{2}{*}{$<0,05$} \\
\cline { 2 - 4 } & Thô và rất thô & $0 / 50(0 \%)$ & $19 / 50(38 \%)$ & \\
\hline $\begin{array}{l}\text { Sừng hóa xung quanh } \\
\text { lỗ núm vú }\end{array}$ & Bình thường (con) & $45 / 50(90 \%)$ & $27 / 50(54 \%)$ & \multirow{2}{*}{$<0,05$} \\
\cline { 2 - 4 } & Bị sừng hóa & $5 / 50(10 \%)$ & $23 / 50(46 \%)$ & \\
\hline
\end{tabular}

Qua kết quả thử CMT đã xác định khả năng phòng bệnh của kem nano bạc đến tỷ lệ mắc bệnh viêm vú cận lâm sàng, theo đó kem nano bạc làm giảm tỷ lệ viêm vú cận lâm sàng theo thời gian sử dụng trong khi với phương pháp phòng thông thường thì tỷ lệ này lại tăng lên (bảng 8). Từ kết quả này chúng tôi nhận thấy, khi sử dụng kem nano bạc trong phòng bệnh viêm vú ở bò đã làm giảm tỷ lệ viêm vú cận lâm sàng và tốt nhất sau 60 ngày sử dụng. Zhao và Stevens (1998) cho rằng, so với các kim loai khác, bạc biểu hiện mức độc tính cao hơn đối với vi sinh vật trong khi nó không có độc tính đối với tế bào động vật có vú. Như vậy, để phòng bệnh viêm vú sau khi điều trị thì trong suốt thời gian bò vắt sữa nên sử dụng kem nano bạc để phòng bệnh viêm vú cho bò, và hiệu quả có thể phòng được tới 93,62\%.
Khi sử dụng các biện pháp phòng bệnh, mẫu sữa vẫn xuất hiện các loại vi khuẩn Staphylococcus spp., Streptococcus spp., E. coli và nấm, tuy nhiên, tỷ lệ này không cao. Đặc biệt, nấm và $E$. coli không thấy xuất hiện trong mẫu sữa của bò sử dụng kem nano bạc trong khi vẫn còn có ở trong mẫu sữa của lô đối chứng với tỷ lệ lần lượt là 2 và $4 \%$ (bảng 9).

Bệnh viêm vú thường bị tác động bởi hỗn hợp vi khuẩn $E$. coli, $S$. aureus, $P$. aeruginosa và $S$. agalactae (Kaoud \& Yosseif, 2013).. Nghiên cứu gần đây đã chứng minh hiệu quả của nano bạc đối với 3 loài vi khuẩn này (Yuan et al., 2017). Như vậy, việc sử dụng kem nano bạc có khả năng phòng bệnh viêm vú và không làm ảnh hưởng nhiều đến sức khỏe bầu vú, không 
làm tăng tỷ lệ viêm vú ở bò sữa. Đặc biệt duy trì sử dụng kem nano bạc bôi ở bên ngoài núm vú và bầu vú phòng bệnh viêm vú tái phát trở lại.

Bảng 8. Tỷ lệ viêm vú cận lâm sàng của bò thí nghiệm

\begin{tabular}{|c|c|c|c|c|c|c|c|c|}
\hline \multirow[b]{2}{*}{ Chỉ tiêu } & \multicolumn{3}{|c|}{ Thí nghiệm } & \multicolumn{3}{|c|}{ Đối chứng } & \multirow[b]{2}{*}{$\begin{array}{l}\text { Chi- } \\
\text { Square }\end{array}$} & \multirow[b]{2}{*}{$\mathrm{P}$} \\
\hline & $\begin{array}{l}\text { Số mẫu } \\
\text { (sữa) }\end{array}$ & $\begin{array}{c}\text { Số mẫu } \\
(+)\end{array}$ & $\begin{array}{l}\text { Tỷ lệ } \\
\text { (\%) }\end{array}$ & $\begin{array}{l}\text { Số mẫu } \\
\text { (sữa) }\end{array}$ & $\begin{array}{c}\text { Số mẫu } \\
(+)\end{array}$ & $\begin{array}{l}\text { Tỷ lệ } \\
\text { (\%) }\end{array}$ & & \\
\hline Trước TN & 40 & 10 & 25,00 & 41 & 9 & 21,95 & 0,105 & $>0,05$ \\
\hline Ngày thứ 15 & 41 & 9 & 21,95 & 43 & 7 & 16,28 & 0,348 & $>0,05$ \\
\hline Ngày thứ 30 & 44 & 6 & 13,64 & 39 & 11 & 28,21 & 2,694 & $>0,05$ \\
\hline Ngày thứ 45 & 44 & 6 & 13,64 & 36 & 14 & 38,89 & 6,734 & $<0,05$ \\
\hline Ngày thứ 60 & 47 & 3 & 6,38 & 35 & 15 & 42,86 & 15,578 & $<0,05$ \\
\hline Sau TN 7 ngày & 46 & 4 & 8,70 & 35 & 15 & 42,86 & 12,919 & $<0,05$ \\
\hline
\end{tabular}

Bảng 9. Số lượng và loại vi khuẩn có trong mẫu sữa bò thí nghiệm

\begin{tabular}{|l|l|c|c|c|}
\hline \multicolumn{2}{|l|}{ Vi sinh vật } & $\begin{array}{c}\text { Lô thí nghiệm } \\
(\mathrm{n}=50)\end{array}$ & $\begin{array}{c}\text { Lô đối chứng } \\
(\mathrm{n}=50)\end{array}$ & $\mathrm{P}$ \\
\hline \multirow{2}{*}{ Staphylococcus spp. } & S. aureus & $1 / 50(2 \%)$ & $1 / 50(2 \%)$ & $>0,05$ \\
\cline { 2 - 5 } & CNS & $10 / 50(20 \%)$ & $14 / 50(28 \%)$ & $>0,05$ \\
\hline \multirow{2}{*}{ Streptococcus spp. } & Streptococcus Agalactiae & $1 / 50(2 \%)$ & $3 / 50(7,5 \%)$ & $>0,05$ \\
\cline { 2 - 5 } & Streptococcus khác & $13 / 50(26 \%)$ & $13 / 50(26 \%)$ & - \\
\hline Escherichia coli & $0 / 50(0 \%)$ & $2 / 50(4 \%)$ & $>0,05$ \\
\hline Nấm & $0 / 50(0 \%)$ & $1 / 50(2 \%)$ & $>0,05$ \\
\hline
\end{tabular}

Khả năng phòng bệnh viêm vú của kem nano bạc ở giai đoạn cạn sữa

Để phòng bệnh viêm vú ở giai đoạn cạn sữa của kem nano bạc, kem được bôi vào núm vú 2 lần trong ngày và tiến hành quan sát đánh giá sức khỏe bầu vú bò. Đánh giá tỷ lệ viêm vú lâm sàng và tỷ lệ nhiễm khuẩn trong mẫu sữa 1-2 giờ từ bầu vú bò sau sinh. Kết quả cho thấy, kem nano bạc duy trì sức khỏe bầu vú tốt hơn so với lô đối chứng (bảng 10). Sử dụng kem nano bạc phòng bệnh viêm vú ở bò trong giai đoạn cạn sữa đảm bảo sức khỏe bầu vú tôt hơn so với các biện pháp phòng bệnh thông thường.

Bảng 10. Kết quả đánh giá tình trạng sức khỏe bầu vú bò

\begin{tabular}{|l|l|c|c|c|}
\hline \multicolumn{2}{|c|}{ Chỉ tiêu } & $\begin{array}{c}\text { Lô thí nghiệm } \\
(\mathrm{n}=25)\end{array}$ & $\begin{array}{c}\text { Lô đối chứng } \\
(\mathrm{n}=25)\end{array}$ & \multirow{2}{*}{$\mathrm{P}$} \\
\hline \multirow{2}{*}{ Màu sắc } & Bình thường (con) & $22 / 25(88 \%)$ & $20 / 25(80 \%)$ & \multirow{2}{*}{$>0,05$} \\
\cline { 2 - 4 } & Sưng, đỏ & $3 / 25(12 \%)$ & $5 / 25(20 \%)$ & \\
\hline \multirow{2}{*}{ Độ khô của da } & Bình thường (con) & $24 / 25(96 \%)$ & $18 / 25(72 \%)$ & \multirow{2}{*}{$<0,05$} \\
\cline { 2 - 4 } & Thô và rất thô & $1 / 25(4 \%)$ & $7 / 25(17 \%)$ & \\
\hline \multirow{2}{*}{$\begin{array}{l}\text { Sừng hóa xung } \\
\text { quanh lỗ núm vú }\end{array}$} & Bình thường (con) & $23 / 25(92 \%)$ & $17 / 25(68 \%)$ & \multirow{2}{*}{$<0,05$} \\
\cline { 2 - 4 } & Bị sừng hóa & $2 / 25(8 \%)$ & $8 / 25(32 \%)$ & \\
\hline
\end{tabular}


Giai đoạn cạn sữa, đặc biệt 15 ngày trước khi đẻ, bò rất dễ bị nhiễm khuẩn hệ thống vú dẫn đến viêm vú. Trong thời gian sử dụng kem nano bạc 15 ngày trước khi đẻ và sau đó xác định tỷ lệ viêm vú lâm sàng và cận lâm sàng sau khi bò đẻ 1-2 giờ. Kết quả cho thấy, trong số 25 bò cái theo dõi, bò được phòng bệnh bằng kem nano bạc đã không xuất hiện viêm vú cận lâm sàng và lâm sàng trong khi lô đối chứng đã có $2(8,0 \%)$ bò xuất hiện viêm vú. Điều này cho thấy khả năng phòng bệnh của kem nano bạc trước khi đẻ ít nhất 15 ngày là hiệu quả.

Xác định vi khuẩn cho thấy lô bò sử dụng kem nano bạc, số lượng loài vi khuẩn xuât hiện ít hơn so với lô đối chứng (bảng 11). Đặc biệt là khả năng hạn chế được các bào tử nấm phát triển của kem nano bạc, đây là một điều khá quan trọng vì viêm vú do nấm gây ra rất khó điều trị trên bò sữa.

Theo Nasrollahi et al. (2011), nano bạc có khả năng diệt các bào tử nấm, tác dụng này cũng đã được khẳng định trong một số nghiên cứu khác (Żhang et al., 2016; Bondarenko et al., 2013). Như vậy, sử dụng kem nano bạc trong phòng bệnh viêm vú ở bò có tác dụng hạn chế các loại vi khuẩn, nấm gây viêm vú và hạn chế tối đa bệnh viêm vú lâm sàng, cận lâm sàng sau khi bò đẻ $1-2$ giờ. Đồng thời hạn chế các loài vi khuẩn và nâm có khả năng gây viêm vú ở bò sữa.

Bảng 11. Số lượng và loại vi khuẩn có trong mẫu sữa

\begin{tabular}{|l|l|c|c|c|}
\hline \multicolumn{2}{|c|}{ Vi sinh vật } & $\begin{array}{c}\text { Lô thí nghiệm } \\
(\mathrm{n}=25)\end{array}$ & $\begin{array}{c}\text { Lô đối chứng } \\
(\mathrm{n}=25)\end{array}$ & $\mathrm{P}$ \\
\hline \multirow{2}{*}{ Staphylococcus spp. } & S. aureus & $0 / 25(0 \%)$ & $0 / 25(0 \%)$ & \\
\cline { 2 - 5 } & CNS & $4 / 25(16 \%)$ & $5 / 25(20 \%)$ & $>0,05$ \\
\hline \multirow{2}{*}{ Streptococcus spp. } & Streptococcus Agalactiae & $1 / 25(4 \%)$ & $0 / 25(0 \%)$ & \\
\cline { 2 - 5 } & Streptococcus khác & $4 / 25(16 \%)$ & $6 / 25(24 \%)$ & $>0,05$ \\
\hline Escherichia coli & $0 / 25(0 \%)$ & $1 / 25(4 \%)$ & \\
\hline Nấm & $0 / 25(0 \%)$ & $1 / 25(4 \%)$ & \\
\hline
\end{tabular}

Khả năng điều trị bệnh viêm vú giai đoạn tiết sữa của kem nano bạc

Ngoài tác dụng để phòng bệnh, kem nano bạc có ý nghĩa cộng hưởng trong việc điều trị bệnh viêm vú ở bò sữa. Kết quả theo dõi 15 bò được điều trị, hiệu quả điều trị viêm vú đạt cao nhất ở phác đồ 3 đến $93,33 \%$ so với phác đồ $2(73,33 \%)$ và phác đồ $1(46,76 \%)$. Thực tế khi triển khai thí nghiệm, những trường hợp viêm vú do vi khuẩn môi trường như $E$. coli, $\mathrm{CNS}, \ldots$ gây viêm vú với những biểu hiện như sữa có chứa bã đậu thì áp dụng phác đồ 1 thu được kết quả rất khả quan. Có thể coi phương pháp này giúp cho việc đảm bảo an toàn thực phẩm và tiết kiệm chi phí cho người chăn nuôi trong việc điều trị bệnh viêm vú. Đối với những vi khuẩn gây bệnh viêm vú truyền nhiễm như $\mathrm{SA}$ và $\mathrm{SAG}$, vi khuẩn xâm nhập sâu vào trong thùy vú nơi có các tế bào tiêt sữa thì rất cần có sự tác động toàn thân như kháng sinh. Tuy nhiên, với việc ngăn chặn vi khuẩn bội nhiễm từ môi trường và việc tiêu diệt vi khuẩn xâm nhập sâu vào bên trong bầu vú của ceftiofur trong phác đồ 3 đã giúp cho tỷ lệ khỏi bệnh viêm vú đạt cao nhất $(93,33 \%)$. Trong nghiên cứu này, chúng tôi chọn đại diện của nhóm cephalosporin là Ceftiofur vì kháng sinh ceftiofur không thải trừ qua sữa, hạn chế sự tồn dư kháng sinh trong sữa.

Theo Kaoud \& Yosseif (2013) áp dụng các phác đồ điều trị viêm vú trên bò gây ra bởi $\mathrm{SA}, \mathrm{SAG}$ và E.coli thu được kết quả như sau: với phác đồ 1 dùng ceftiofur bơm vào bầu vú tỷ lệ khỏi bệnh là $60 \%$; phác đồ 2 dùng Ceftiofur bơm vào bầu vú và tiêm bắp bằng chất kháng viêm và Enrofloxacin tỷ lệ khỏi bệnh là $80 \%$, phác đồ 3 dùng nano bạc bơm vào bầu vú tỷ lệ khỏi bệnh là $60 \%$. Trong nghiên cứu của chúng tôi nano bạc được sử 
dụng ở dạng kem nên chỉ có thể bôi ngoài da để ngăn chặn và tiêu diệt vi khuẩn bám trên bề mặt da vú ngăn cho chúng xâm nhập sâu vào bên trong vì thế những vi khuẩn đã xâm nhập gây viêm vú bên trong không tiêu diệt được nên tỷ lệ khỏi thấp hơn (46,67\%). Khi áp dụng kháng sinh để điều trị viêm vú, tỷ lệ khỏi bệnh là $93,33 \%$, cao hơn so với nghiên cứu của Kaoud \& Yosseif (2013) (60\%). Kết quả này có thể do Ceftiofur hiện ít được dùng để điểu trị trên đàn bò thí nghiệm trước đó nên ít gây ra hiện tượng kháng thuốc, hơn nữa, khi kêt hợp giữa kháng sinh tiêm bắp và thuốc kháng viêm giúp hiệu quả điều trị bệnh tăng lên, giảm các triệu chứng viêm nhanh hơn.

\section{KẾT LUẬN}

Kem nano bạc với carbomer làm chất tạo keo có độ đồng nhất cao và duy trì được lâu dài với nồng độ tối ưu của carbomer là $0,4 \%$ và nồng độ nano bạc là $150 \mathrm{ppm}$. Kem có thành phần nano bạc ở nông độ từ 50-250 ppm có khả năng diệt ba loài vi khuẩn như $E$. coli, $P$. aeruginosa và $S$. aureus.

Kem nano bạc nồng độ 150 ppm có tác dụng tối đa phòng bệnh viêm vú lâm sàng và cận lâm sàng của bò trước khi đẻ. Tỷ lệ khỏi bệnh viêm vú lâm sàng là 46,67\%, khi kết hợp với kháng sinh ceftiofer hiệu quả điều trị đạt $93,33 \%$.

Để phòng bệnh viêm vú bò sữa, sử dụng kem nano bạc tốt nhất trước khi đẻ 15 ngày và toàn bộ thời gian trong giai đoạn vắt sữa. Sử dụng kết hợp kem nano bạc trong điều trị bệnh viêm vú với kháng sinh đưa lại hiệu quả cao.

Lòi cảm onn: Công trình được thực hiện trong khuôn khổ Dự án KHCN trọng điểm cấp Viện Hàn lâm KHCNVN "Nghiên cúu úng dụng công nghẹ nano trong nông nghiệp", Mã số VAST.TĐ.NANO-NN/15-18.

\section{TÀI LIỆU THAM KHẢO}

Akmaz S, Adiguzel E. D., Yasar M., Erguven O., 2013. The effect of Ag content of the chitosan-silver nanoparticle composite material on the structure and antibacterial activity. Advances in Materials Science and Engineering. Volume 2013, Article ID
690918, 6 pages. https://dx.doi.org/10. 1155/2013/690918

Anri A., Kanameda M., 2002. Tập huấn về Bệnh viêm vú bò sữa: Phương pháp chẩn đoán trong phòng thí nghiệm và kiểm soát hiệu quả tại Việt Nam, Bản dịch, lưu hành nội bộ. Dự án Nâng cao năng lực JICA - Viện Thú y, tr. 15-22.

Anri A., Nguyễn Thị Kim Anh, Trần Thị Hạnh, 2005. Các quy trình xét nghiệm phát hiện vi sinh vật gây bệnh viêm vú cận lâm sàng ở bò sữa. JICA - NIAH.

Berni E., Marcato P. D., Nakazoto G., Kobayashi R. K. T., Vacchi F. I., Umbuzeiro G. A., Durán N., 2012. Violacein/poly (E-caprolactone)/chitosan nanoparticles against bovine mastitstis: Antibacterial and ecotoxicity evaluation. International Conferences on Safe Production and Use of Nanomaterials. Jounal of Physics: Conference Series, 429: 1-7.

Birla S. S., Tiwari V. V., Gade A. K., Ingle A. P., Yadav A. P., Rai M. K., 2009. Fabrication of silver nanoparticles by Phonma glomerata and its combined effect against Escherichia coli, Pseudomonas aeruginosa and Staphylococcus aureus. Lett Appl Microbiol., 48: 173-179.

Bondarenko O., Ivask A., Kakinen A., Kurvet I., Kahru A., 2013. Particle-cell contact enhances antibacterial activity of silver nanoparticles. PloS ONE 2013 e64060.

Bradley A. J., Leach K. A., Breen J. E., Green L. E., Green M. J., 2007. Survey of the incidence and aetiology of mastitis on dairy farms in English and Wales, Veterinary Record, 160, p. 253-258.

Cheng Y, Wang F., Fang C., Su J., Yang L., 2016. Preparation and characterization of size and morphology controllable silver nanoparticles by citrate and tannic acid combined reduction at a low temperature. J. Alloy. Compd., 658: 684-688.

Humberto H. L., Elsa N. G. T., Liliana I. T., Dinesh K. S., 2011. Silver nanoparticles are broad-spectrum bactericidal and 
virucidal compounds. Laraet al. Journal of Nanobiotechnology, 2011, 9:30. http://www.jnanobiotechnology.com/cont ent $/ 9 / 1 / 30$.

Idriss Sh. E., Foltys V., Tancin V., Kirchnerová K., Tancinoá D., Zaujec K., 2014. Mastitis pathogen and their resistance against antimicrobial agents in dairy cow in Nitra, Slovakia. Slovak Journal of Animal Science, 47(1): 33-38.

Kaoud H. A, Yosseif S., 2013. Innovative method for the treatment of mastitis in dairy animals. The Journal of Veterinary Science. Photon., 114: 240-244.

Kumar A. P., Parida P., 2015. Development and Evaluation of Gel Incorporated with Biogenically Synthesised Silver Nanoparticles. Journal of Applied Biopharmaceutics and Pharmacokinetics, 3, $1-6$.

Marslin G., Selvakesavan R. K., Franklin G., Sarmento B., Dias A. C. P., 2015. Antimicrobial activity of cream incorporated with silver nanoparticles biosynthesized from Withania somnifera. Int. J. Nanomedicine, 2015(10): 5955-5963.

Mein G. A., Neijenhuis F., Morgan W. F., Reinemann D. J., Hillerton J. E., Baines J. R., Ohnstad I., Rasmussen M. D., Timms L., Britt J. S., Farnsworth R., Cook N. B., Hemling T., 2001. Evaluation of bovine teat condition in commercial dairy herds: 1. Non - infectious factors. Proceedings of the $2^{\text {nd }}$ International Symposium on Mastitis and Milk Quality.
Nasrollahi A., Pourshamsian Kh., Mansourkiaee P., 2011. Antifungal activity of silver nanoparticles on som of fungi. Int. J. Nano. Dim., 1: 233-239.

Perugini B. G., R, E. Otaguniri S., Morey A. T., 2015. Effect of Eugenol against streptococcus agalactiae and Synergistic Interaction with Biologically Produced Silver Nanoparticles. Evid Based Complement Alternat Med. 2015:861497. doi:10.1155/2015/861497.

Nguyễn Như Thanh, Nguyễn Bá Hiền, Trần Thị Lan Hương, 1997. Vi Sinh Vật Thú y. Nxb Nông Nghiệp, H.: 60-96.

Wilson W., 2012. Consumer products inventory Project on Emerging Nanotechnologies, Woodrow Wilson International Center for Scholars.

Yuan Y. G, Peng Q. L., Gurunathan S., 2017. Effects of silver nanoparticles on mutiple drug-resistant strains of Staphylococcus aureus and Pseudomonas aeruginosa from mastitis-tifectied Goat: An alternative approach for antimicrobial therapy. Int. J. Mol. Sci., 2017(18): 569.

Zhang X. F., Shen W., Gurunathan S., 2016. Silver Nanoparticle-Mediated Cellular Responses in Various Cell Lines: An in Vitro Model. Int. J. Mol. Sci., 17: 1603.

Zhao G. J, Stevens S. E., 1998. Multiple parameters for the comprehensive evaluation of the susceptibility of Escherichia coli to the silver ion. Boimetals, 11: 27-32. 